\title{
A study on commercial cultivation and storage of water chestnut (Trapa natans L.) under wetland ecosystem of North Bihar, India
}

\author{
B. R. Jana* \\ ICAR-RCER, Research Centre for Makhana, Darbhanga-846005 (Bihar), India \\ B. P. Bhatt \\ ICAR-RCER, ICAR Parishar, Patna-800014 (Bihar), India \\ I. S. Singh \\ ICAR-RCER, Research Centre for Makhana, Darbhanga-846005 (Bihar), India \\ Md. Idris \\ ICAR-RCER, Research Centre for Makhana, Darbhanga-846005 (Bihar), India \\ *Corresponding author. E-mail: brjana.ars@gmail.com
}

\begin{abstract}
Water chestnut is an excellent economical and medicinal winter crop from fresh water ecosystem. It is well known for its nutrient content including protein and antioxidants. Different water chestnut germplasm viz. Green Spineless, Green Spine, Red Spineless and Red Spine were studied at wetland ecosystem of North Bihar in India under Research Centre on Makhana, Darbhanga, during 2016-17. Under wetland ecosystem, Green Spineless variety of water chestnut produced large quality nut $(24.42 \mathrm{~g})$ followed by Red Spineless $(23.11 \mathrm{~g})$. Regarding yield, Green Spineless gave rise to the maximum yield of $12.24 \mathrm{t} / \mathrm{ha}$. The Red Spineless variety exhibited the maximum TSS of $9.6^{\circ} \mathrm{B}$ followed by Green Spineless $\left(9.2^{\circ} \mathrm{B}\right)$. Water chestnut beetle (Galerucella birmanica Jacoby.) was dangerous pest under wet land ecosystem as compared to aphid. Green colored varieties were resistant to beetle and aphid. Different approaches had been made to enhance the shelf life of water chestnut variety Red Spineless as it was sweetest and attractive in colour among trial varieties. The results revealed that poly packaging with $5 \%$ perforation and stored in refrigerator for $4^{\circ} \mathrm{C}\left(\mathrm{T}_{1}\right)$ increased storage life up to 14.0 days as compared to open ambient $\left(\mathrm{T}_{4}\right)$ (4.72 days) maintaining fair market acceptability. This treatment $\left(T_{1}\right)$ also improved the TSS content of the fruit to $9.8^{\circ} \mathrm{B}$ by slow and gradual PLW about $21.15 \%$ during two weeks of storage. From our present study it may be concluded that irrespective of color, spineless varieties of water chestnut were promising under wetland ecosystem of North Bihar on account of their yield potential and nut quality.
\end{abstract}

Keywords: Cultivation, Disease and pest, Fruit quality, Storage, Water chestnut, Yield.

\section{Article Info}

DOI:10.31018/jans.v11i2.2105

Received: May 5, 2019

Revised: June 4, 2019

Accepted: June 9, 2019

\section{How to Cite}

Jana, B. R. et al. (2019). A study on commercial cultivation and storage of water chestnut (Trapa natans L.) of wetland ecosystem of North Bihar, India. Journal of Applied and Natural Science, 11(2): 528 - 533 https://doi.org/10.31018/ jans.v11i2.2105

\section{INTRODUCTION}

Water chestnut is one of the most important aquatic nut crop grown in wetland ecosystem of India. It is a floating aquatic plant that grown in marshes and shallow lakes of tropical and subtropical origin (Takano and Kadono, 2005). It is believed to be native of Europe and Asia where well acquainted with different names viz; devil's pod, buffalo nut, water caltrop (Hummel and Kiviat 2004 and Hummel and Findlay, 2006). It belongs to the family Lythraceae or trapaceae and has three different species like $T$. bispinosa, $T$. natans and $T$. quadrispinosa or T. bicornis. In India, it is mainly cultivated in Bihar, West Bengal, M.P. and lower parts of Uttaranchal, UP and Orissa. It is easy growing water plant, thrives best in soft nutrient rich water of lakes and shallow ponds. Water chestnut is mainly available after rainy season to mid winter. Fresh nut is well known for its high water content (80\%) (Puste, 2004), starch (52\%), protein $(1.87 \%)$ and TSS $(7-8 \%)$ (Singh et al., 2010). Apart from these quality attributes, it is good source of fiber, Vitamin B along with $\mathrm{Ca}, \mathrm{K}$, Fe and Zn. According to Adkar et al., (2014) and Alfasane et al., (2011), protein and carbohydrate content of fresh water chestnut were $4.40 \%$ and $22.3 \%$, respectively. Water chestnuts are excellent source of crude fiber and it was for green variety $2.13 \%$ and Red variety $2.27 \%$ (Faruk et al., 2012) and carbohydrates and protein (Singh et al., 2009). Water chestnuts are cholesterol and gluten free and have cooling and detoxifying effects. Even, water chestnuts are known to aid in curing jaundice. Besides, carbohydrates and protein water chestnut contained fair amount of flavonoid and antioxidant thus can be a potential source of nutrition (Mann et al., 2011). It is a knobby edible 
nut with a reddish black and pure green skin and a white crunchy flesh. The people of Mithilanchal used the fruits as raw and boiled and consumed after separation of skin which have a sweet taste with a slight crunch, somewhat nutty as that of boiled potato. Boiled water chestnut removes free water and toxins which could cause for cough and cold. In addition, according to Akao et al., (2014), the floating parts of water chestnut contained high concentrations of total phenolics, which inhibited growth of Microcystis aeruginosa and the crude extracts. Water chestnut used to add important quantities of nitrogen, phosphorus, and potassium $(1.49,1.05$, and $16.3 \mathrm{mg} \mathrm{g}-1)$, respectively. Water chestnut is environment friendly and utilized in higher nut production, prevention of cyanobacterial bloom and addition of nutrients to the soil. Nutritional and medicinal qualities of Trapa natans had been recognized in India, China, Hong Kong, Malaya, Thailand, and Russia (Hummel and Kiviat 2004). It is also recommended as a cattle feed supplement (Besha and Countryman, 1980). Trapa natans usually decrease dissolved inorganic nitrogen in water thereby potentially reducing eutrophication process (Tsuchiya and Iwakuma 1993). From aquatic environment, it adsorbs heavy metals such as cadmium, nickel, and cobalt (USEPA, 1989). It has enough amount of potassium, which helps to counter the effect of sodium and good for lowering blood pressure as well as heart of human. With efficient cultural practices, one seed gives rise to 10-12 rosettes and each rosette produces as much as 20 fruits (Rhoads and Morris, 2002). Therefore, present investigation was performed with a view to develop commercial cultivation process of water chestnut eco-friendly and their commercial storage for better market availability with high return.

\section{MATERIALS AND METHODS}

Experiment was conducted at ICAR-RCER, Research Centre on Makhana, Darbhanga, Bihar, during 2016-17 to assess the suitable water chestnut varieties and various techniques to increase water chestnut production under wet land ecosystem of North Bihar. Data were taken on broad aspects and they were sub categorized under following points:

Agronomical practices: Yield performance was calculated by multiplying the plant population with no of fruits and individual fruit weight. TSS of fresh fruits was observed by hand held refractrometer. Acidity was calculated by in terms of citric acid equivalent and expressed as per cent (Ranganna, 1986). The physiological loss of water (PLW) and nut volume were measured by standard methods. Planting distance was $1 \mathrm{mx} 2 \mathrm{~m}$ and plant population was $>4500 /$ ha. We applied higher fertilizer dose for N: P: K 60:20:20 /ha for new plot or low- land for introduction of water chestnut. For cultivation in old plot fertilizer dose was almost half because biomass decomposition of previous crop provided rest of the nutrient to soil. After transplantation, water level was maintained about $1.0 \mathrm{~m}$ deep. We prepared shallow land at our research station which was $1.5 \mathrm{~m}$ deep. The cultivars under study were Spine Red, Spine Green, Spineless Red and Spineless Green. Each cultivar treated as each treatment and the replicationswerefive. Two years data were pooled and average data were analyzed by adopting randomized block design (WASP 2.0).

Pest and diseases infestation: The research plots were examined carefully. Aphid and beetle (Galerucella birmanica Jacoby.) were the main pest under wetland ecosystem of Darbhanga, North Bihar. Pest infestation was measured by number of infested plants with in total plant population in a particular plot. Infested plant was marked when at least $5.0 \%$ of leaves i.e. 2-3 leaves get affected. Two years observations regarding pest population and infestation were taken and average data were computed and described.

Nutrient dynamics: In our experiment, we determined available $\mathrm{N}$ and $\mathrm{P}$ and exchangeable $\mathrm{K}$ from soil samples. Available N ( $\mathrm{kg} / \mathrm{ha}$ ) in the soil samples was measured by the method described by Subhiah and Asija (1956). In case of available $\mathrm{P}(\mathrm{kg} / \mathrm{ha})$ in the soil samples was determined with the vanodo-molybdophosphoric acid yellow-colour method (Jackson, 1973). Exchangeable K (kg /ha) in the soil samples was determined by the flame photometric method (Jackson, 1973). Two years data were pooled and average data were depicted. The same methods were used to analyze the plant samples.

Commercial storage: In addition to agronomical practices, we tried different packaging methods and storage of water chestnut to reduce market glut with a view to get better remuneration by the farmer. We imposed five treatments viz; $\mathrm{T}_{1}=$ Polypacking with $5 \%$ holes/perforation at $4{ }^{0} \mathrm{C}, \mathrm{T}_{2}=$ Open at $4{ }^{\circ} \mathrm{C}$ ambient, $\mathrm{T}_{3}=$ Poly-packing with $5 \%$ holes at ambient, $\mathrm{T}_{4}=$ Open at ambient and $\mathrm{T}_{5}=$ Submerged in water (Cold $=10-15^{\circ} \mathrm{C}$ ). Data were taken on PLW, volume,TSS and acidity for storage samples. Acidity was calculated by in terms of citric acid equivalent and expressed as per cent. PLW and nut volume were measured by standard methods. Two years data were pooled and average data were analyzed by adopting completely randomized design (WASP 2.0) with four replications.

\section{RESULTS AND DISCUSSION}

We examined various data on agronomical practices and yield, pest and diseases, nutrient dynamics, post harvest quality of fruits and different approaches to enhance productivity and food and 
Jana, B. R. et al. / J. Appl. \& Nat. Sci. 11(2): 528 - 533 (2019)

Table 1. Physical characteristics and yield of different germplasm of water chestnut during 2016-17.

\begin{tabular}{llllllll} 
S.N. & Varieties & $\begin{array}{l}\text { Fresh wt. of a } \\
\text { whole plant(kg) }\end{array}$ & $\begin{array}{l}\text { No of Plant- } \\
\text { lets /plant }\end{array}$ & $\begin{array}{l}\text { No of Fruits/ } \\
\text { plantlets }\end{array}$ & $\begin{array}{l}\text { Fruit } \\
\text { Weight(g) }\end{array}$ & $\begin{array}{l}\text { Yield } \\
(\mathbf{t}) / \mathbf{h a}\end{array}$ & $\begin{array}{l}\text { TSS } \\
(\mathbf{0} \mathbf{B})\end{array}$ \\
\hline 1. & Red Spineless & 3.95 & 8.36 & 14.65 & 23.11 & 9.69 & 9.60 \\
2. & Red Spine & 3.15 & 7.10 & 12.45 & 20.35 & 7.60 & 7.70 \\
3. & Green Spineless & 4.40 & 9.28 & 15.73 & 24.42 & 12.24 & 9.20 \\
4. & Green Spine & 2.35 & 6.02 & 12.25 & 14.46 & 4.80 & 7.60 \\
& CD at 5 (\%) & $\mathbf{0 . 4 3}$ & $\mathbf{0 . 2 4}$ & $\mathbf{1 . 0 5}$ & $\mathbf{1 . 2 7}$ & $\mathbf{2 . 0 9}$ & $\mathbf{0 . 0 4}$ \\
\hline
\end{tabular}

**pooled data

Table 2. Infestation and damage intensity of water chestnut aphid and beetle during 2016-2017 under wetland ecosystem of North Bihar.

\begin{tabular}{lllllll}
\hline S.N. & Varieties & $\begin{array}{l}\text { Aphid Infes- } \\
\text { tation (\%) }\end{array}$ & $\begin{array}{l}\text { Time of aphid } \\
\text { Infestation }\end{array}$ & $\begin{array}{l}\text { Beetle infesta- } \\
\text { tion(\%) }\end{array}$ & $\begin{array}{l}\text { Time of beetle } \\
\text { Infestation }\end{array}$ & $\begin{array}{l}\text { Economic } \\
\text { Loss }\end{array}$ \\
\hline 1. & Red Spineless & $20 \%$ & Dec-Jan & $30 \%$ & July & No \\
2. & Red Spine & $15 \%$ & Dec & $20 \%$ & August & No \\
3. & Green Spineless & $10 \%$ & Jan & $10 \%$ & July- August & No \\
4. & Green Spine & $10 \%$ & Dec-Jan & $15 \%$ & August & No \\
\hline
\end{tabular}

*Pest infestation was measured by no of infested plants in total plant population in a particular plot. Infested plant was marked when at least $5 \%$ of leaves i.e. 2-3 leaves get affected.

Table 3. Storage study of water chestnut cv. Red Spineless during 2016-2017.

\begin{tabular}{lllllll}
\hline $\mathbf{( T )}$ & Treatments (T) & $\begin{array}{l}\text { Storage } \\
\text { Days }\end{array}$ & $\begin{array}{l}\text { PLW } \\
(\%)\end{array}$ & $\begin{array}{l}\text { Decreased } \\
\text { Fruit Vol. (\%) }\end{array}$ & $\begin{array}{l}\text { Final TSS } \\
\left({ }^{\mathbf{0}} \mathbf{B}\right)\end{array}$ & $\begin{array}{l}\text { Ultimate } \\
\text { Acidity (\%) }\end{array}$ \\
\hline $\mathbf{T}_{\mathbf{1}}$ & Polypack with 5\% holes at 4 ${ }^{0} \mathrm{C}$ & 14.00 & 21.15 & 20.25 & 9.80 & 0.225 \\
$\mathbf{T}_{\mathbf{2}}$ & Open at 4 ${ }^{0} \mathrm{C}$ & 8.55 & 24.02 & 22.50 & 8.50 & 0.102 \\
$\mathbf{T}_{\mathbf{3}}$ & Polypack with 5\% holes at ambient & 6.25 & 24.11 & 23.75 & 7.95 & 0.122 \\
$\mathbf{T}_{\mathbf{4}}$ & Open at ambient & 4.72 & 26.50 & 26.33 & 7.50 & 0.102 \\
$\mathbf{T}_{\mathbf{5}}$ & Submerged in Water[ Cold $\left.=10-15^{\circ} \mathrm{C}\right]$ & 3.51 & 2.15 & 2.26 & 9.10 & 0.326 \\
& [CRD] CD at 5 (\%) & $\mathbf{1 . 0 8}$ & $\mathbf{2 . 4 7}$ & $\mathbf{2 . 1 8}$ & $\mathbf{0 . 7 2}$ & NS \\
\hline
\end{tabular}

${ }^{* *}$ pooled data, ${ }^{* * *}$ Storage periods (2 weeks) up to commercial acceptability, Initial TSS $=9.4{ }^{0} \mathrm{~B}$, Acidity $=0.333$ $\%$. Loss and development data at their respective last storage day. Variety $=$ Red Spineless.

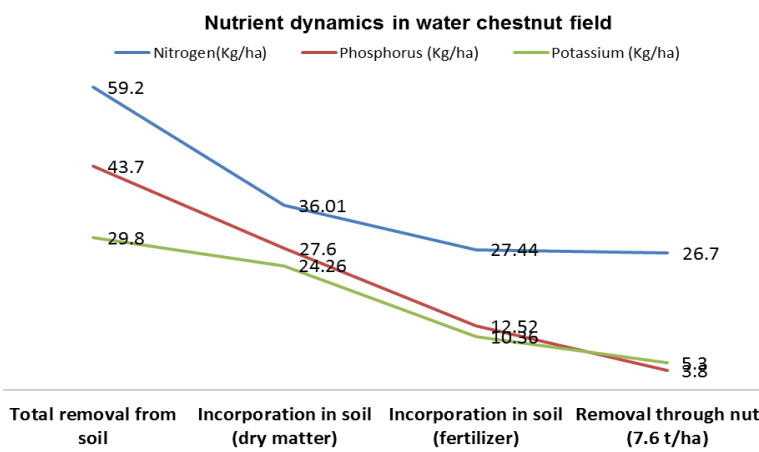

Fig. 1. Nutrient dynamics in water chestnut field (Red Spine variety).

nutritional security of rural people.

Agronomical practices and yield performance: Water chestnut needs rather cool climate for its seed germination $\left(12-15{ }^{\circ} \mathrm{C}\right.$ ) (Kundu and Joshi 2012). For plant growth and development it needs a little bit of higher temperature $25-30^{\circ} \mathrm{C}$. However, fruit is generally harvested during cool winter October-November (Kundu and Joshi 2012, Rhoads and Morris 2002). Flowering period of water chestnut is July -August (Rhoads and Morris 2002). Green varieties of water chestnut bloom first over red varieties (Choudhury, 2003). However, red varieties compete rapid development in later stages of fruit growth. Harvesting of the nut is

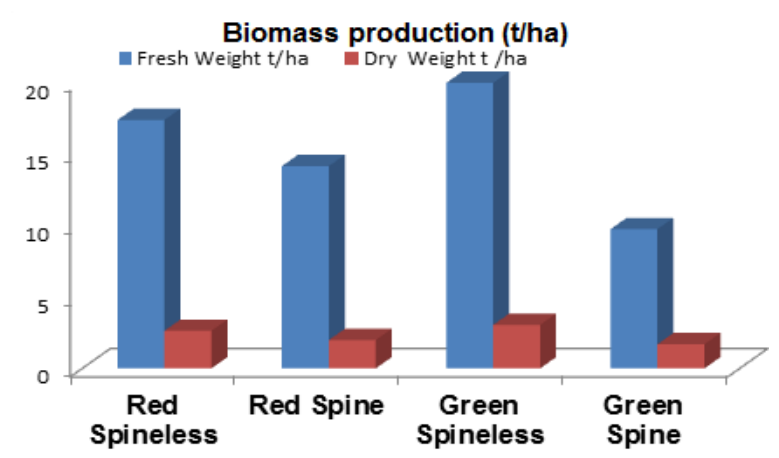

Fig. 2. Biomass production in terms of fresh weight and dry weight.

usually performed during late September and continues up to November. A close perusal of the table -1 revealed that Green Spineless variety of water chestnut plant was vigorous (Fresh biomass, $4.40 \mathrm{~kg} /$ plant ) being comparable with Red Spineless (Fresh biomass, $3.95 \mathrm{~kg} /$ plant) and produced more biomass interms of fresh weight with all plantlets. It has been found that plantlet production was also higher in Green Spineless (9.28 / plant). The maximum fruit production was highest in Green Spineless (15.73/plantlets) followed by Red Spineless (14.65/plantlets).

Regarding total production, Green Spineless accounted for the maximum yield of $12.24 \mathrm{t} / \mathrm{ha}$ as 
Jana, B. R. et al. / J. Appl. \& Nat. Sci. 11(2): 528 - 533 (2019)

Yield increase (\%) of water chestnut

- Yield Increase (per cent)

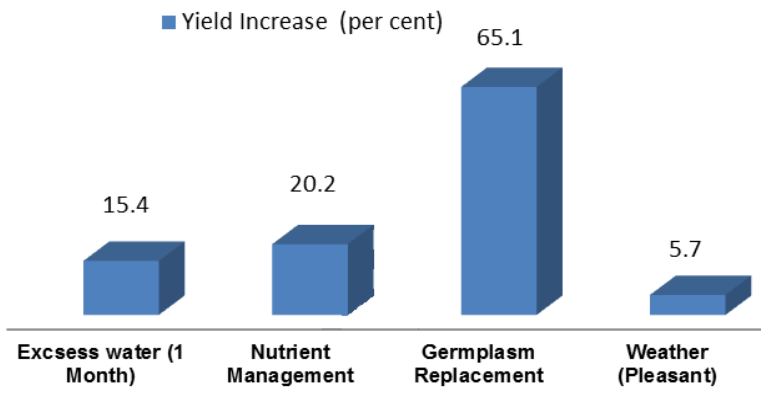

Fig. 3. Salient point for yield increment for commercial cultivation of water chestnut.

Commercial storages and discard (\%) 7.9

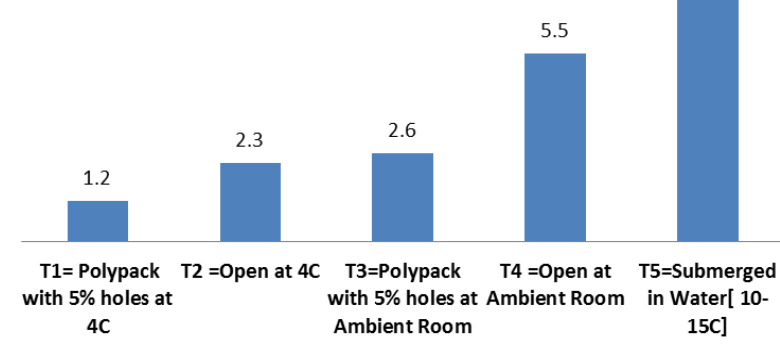

Fig. 4. Discard per cent of water chestnut during different storage condition.

compared to Red Spineless (9.69 t/ha). According to Choudhury et al., (2003) Balasore Green was the highest yielder(16.84 t/ha) and they correlated that green varieties of water chestnut yielded more at Mendhasal, Orisha, India. However, a well maintained local variety gives the maximum yield of 2.5-3.5 t//ha (Kundu and Joshi, 2012 and Jana, 2016). Regarding individual fruit weight Green Spineless gave the maximum fruit weight $(24.42 \mathrm{~g})$ being comparable with the Red Spineless $(23.11 \mathrm{~g})$. In case of Green Spineless production was increased but quality of fruits were diminished. The TSS of water chestnut variety Red Spineless was significantly higher $\left(9.6^{\circ} \mathrm{B}\right)$ than that of other germplasm of water chestnut in trial.

Pest and diseases: Water chestnut beetle, Galerucella birmanica Jacoby. (Coleoptera: Chrysomelidae), was an important pest of water chestnut (Trapa natans L.), and some relative species under wetland ecosystem of North Bihar were also noticed. Yadav and Gargav (1988) also identified Galerucella birmanica Jacoby. as a serious pest for Trapa bispinosa at Jabalpur, India. This pest was widespread in Asia, Europe and USA (Tang et al., 2016). Makhana aphid (Rhopalosiphum nymphaeae) was another insect pest found to attack the water chestnut plant during Dec-Feb in some water chestnut germplasm during 2017 (Table-2). Aphid of water chestnut i.e. ( makhana aphid) attacked the existing plant after harvesting during January and February. It had been found that Red Spineless varieties of water chestnut were more susceptible to aphid as com-

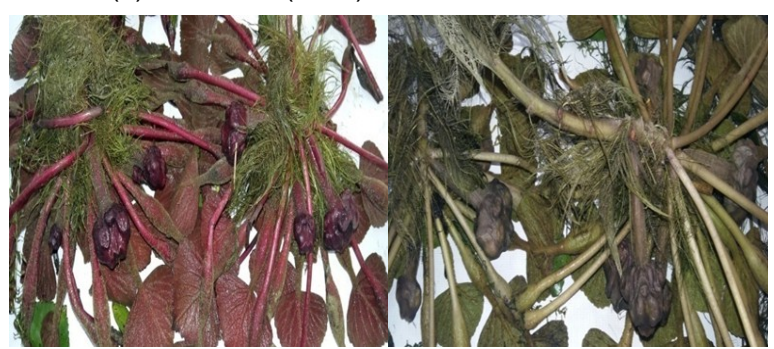

Fig. 5. Spineless Red.

Fig. 6. Spineless Green.

pared to other varieties. Even beetle infestation was more in case of Red Spineless variety.

On the other hand both the aphid and beetle infestation were very less in case of green variety especially Spineless Green which was collected from Jabalpur area of M.P. India. Under wetland ecosystem Spineless Green performed well and gave stable production avoiding any eco-biohazard. A close perusal of the table-2 revealed that Red Spineless variety of water chestnut was subjected to the maximum aphid (20\%) and beetle $(30 \%)$ infestation during December and July of 2016-17, respectively. Green Spineless variety was hardy and had more gestation period and this variety was infected with less intensity. It has also been found that aphid infestation was $10 \%$ during January and beetle infestation was also $10 \%$ during July-August. However, no economic loss was observed as the infestation period of beetle and aphid were on nursery stage or at off season plants.

Nutrient dynamics: As it is an aquatic crop it does not require specific soil for its cultivation. However, for commercial cultivation soil should be heavy, muddy and rich in organic matter. The $\mathrm{pH}$ and organic matter of Darbhanga soil were 7.2 and $0.90 \%$. Organic manures in form of oil cakes, poultry manure, compost /FYM are the best for growth and development of water chestnut crop. The significant amount of phosphorus and potassium are needed for optimum growth of the crop. The application of FYM @ 8 t/ha improves the yield at significant level (Choudhury et al., 2003). In West Bengal, application of $30-40 \mathrm{~kg}$ urea/ha during transplantation and another $20 \mathrm{~kg} / \mathrm{ha}$ is highly recommended after 25-30 days of transplanting (Jana, 2016). The soil rich in $\mathrm{Zn}$ and Boron resulted in increased the number of fruits and their individual weight.

With regard to nutrient dynamics of water chestnut field, total removal from one ha plot was $59.20 \mathrm{~kg}$ $\mathrm{N}_{2}, 43.70 \mathrm{Kg} \mathrm{P}_{2} \mathrm{O}_{5}$ and $29.80 \mathrm{~K}_{2} \mathrm{O}$ (fig-1) in case of Red Spine local variety. In case of new field (shallow farmland) we applied fertilizer $N: P: K$ @60:20:20/ha but after one year of cultivation, the fertilizer dose was N:P:K @ 27.4:12.5:10.3 $\mathrm{kg} / \mathrm{ha}$ because water chestnut biomass was decomposed in the field, which added nutrients and organic matter to soil. Total incorporation in one ha from dry matter and fertilizer application were 
$\mathrm{N}_{2}(36.01+27.44) 63.45 \mathrm{~kg}, \mathrm{P}_{2} \mathrm{O}_{5}(27.60+12.52)$ $40.12 \mathrm{~kg}$ and $\mathrm{K}_{2} \mathrm{O}(24.26+10.36) 34.62 \mathrm{~kg}$. After cultivation, Nitrogen and $\mathrm{K}$ balance was almost same. From present study, we could recommend more phosphate $\left(\mathrm{P}_{2} \mathrm{O}_{5}\right)$ application @ $3.5 \mathrm{~kg} / \mathrm{ha}$ to keep up balanced nutrition in continuously growing field. Singh (2017) also reported that in makhana + water chestnut cropping system, the quantity of available phosphate in soil was low $(20.0 \mathrm{~kg} / \mathrm{ha})$. For new field cultivation present fertilizer dose can be modified from N:P:K @ 60:20:20 kg /ha to N:P:K @ 60:40:30 kg/ha based on nutrition removal data. This study was corroborated by Choudhary et al., (2003) and they applied N:P:K @ 40:60:40 kg/ha under Mendhasal, Odisha, India condition. The Red Spine cultivar produced about $7.60 \mathrm{t}$ nut/ha at Darbhanga, which removed N:P:K @ 26.7: 3.8: 5.3 kg/ha. With regard to biomass production Green Spineless cultivar produced the highest fresh biomass of $19.93 \mathrm{t} /$ ha and dry biomass of $3.03 \mathrm{t} / \mathrm{ha}$ (fig-2). The variety Red Spine produced fresh biomass of $14.12 \mathrm{t} / \mathrm{ha}$ which was equivalent to dry biomass of $1.98 \mathrm{t} / \mathrm{ha}$. Experimental data also provided the information that proper nutrient management enhanced the production by $20.2 \%$, availability of excess water for one month resulted in increased yield by $15.4 \%$, whereas as replacement of existing germplasm with improved Spineless variety excelled the production increase by $65.1 \%$ (Fig-3).

Commercial storage: A close perusal of the Table 3 revealed that when water chestnut was stored in perforated $(5 \%)$ white poly bag at $4{ }^{\circ} \mathrm{C}$ $\left(T_{1}\right)$, the maximum storage period was 14.0 days as compared to open at $4{ }^{0} \mathrm{C}$ at refrigerator $(8.55$ days). The direct freezing temperature might be injurious for fruits and also paved the way for rapid desiccation and product was commercially accepted for 8.55 days and during this period TSS started to increase slightly and after two weeks then it gradually decreased. According to Singh et al (2010) samples kept at frozen conditions exhibited better storage life and the frozen samples illustrated initial increase of TSS and then slow but gradual decline in TSS over the storage period. The storage life at ambient storage with poly bags was 6.25 days as compared to open ambient 4.72 days $\left(T_{4}\right)$. When the product was submerged in water $\left(10-15^{\circ} \mathrm{C}\right)$ it can be stored effectively for 3.51 days $\left(T_{5}\right)$. After that the colour of water chestnut get decreased/faded, but the nut quality remained almost same. The maximum PLW was found in ambient opened $\left(T_{4}\right)$ condition $(26.50 \%)$ as compared to water storage $\left(T_{5}\right)$ $(2.15 \%)$. Similar trend was also observed in case of nut volume which decreased to $26.33 \%$ in open ambient and to $2.26 \%$ in water storage. In case biochemical changes under different storage condition the acidity was insignificant among the different storage treatments. Total acid in terms of citric acid present was $0.142 \%$ which was higher as reported by Majumdar and Jana (1977). The TSS content was maximum of $9.8^{\circ} \mathrm{B}$ in $\mathrm{T}_{1}$ treatment this might be due to slow and steady PLW throughout the 14.0 days of storage period and where the conversion of starch to sugar was effective. In a different study Singh et al., (2010) also found that the total soluble solids content of the fruit was $7.2^{\circ} \mathrm{B}$ confirming presence of good amount of sugars at storage.

On the other hand, in present study, there was rapid increase and then final decrease of TSS to $7.95^{\circ} \mathrm{B}\left(\mathrm{T}_{3}\right)$ for poly pack ambient and $7.50^{\circ} \mathrm{B}\left(\mathrm{T}_{4}\right)$ for open ambient treatments. According to Singh et al (2010), in first 10 days TSS of the frozen sample increased from 7.2 to $8.2^{\circ} \mathrm{B}$ then decline to $3.9^{\circ} \mathrm{B}$. In our studies submerged samples kept its nutritional quality same. Furthermore, in present study, decrease in total acidity and total soluble solids were observed in all fruits kept in different storage temperatures during more than two weeks of storage. The maximum discard \% was observed in $\mathrm{T}_{5}$ treatment, which was about $7.9 \%$ and it was only due to lack of retention of original colour (Fig-4). The Red Spineless variety (Fig-5) of water chestnut was attractive over Green Spineless (Fig-6).

\section{Conclusion}

From the present study, it can be concluded that Green Spineless and Red Spineless varieties were promising under wetland ecosystem of North Bihar, regarding their yield and TSS content. In the context of fertilizer schedule, the crop required more phosphate $\left(\mathrm{P}_{2} \mathrm{O}_{5}\right)$ but $\mathrm{N}_{2}$ and $\mathrm{K}_{2} \mathrm{O}$ were appropriate for proper growth and development. With regard to commercial storage the shelf life of Red Spineless cultivar was 14.0 days at $4^{\circ} \mathrm{C}$ under poly packaging with $5 \%$ perforations. Germplasm replacement is still the effective way to increase the crop production for food and nutritional security of rural people.

\section{REFERENCES}

1. Adkar, P., Dongare, A., Ambavade, S. and Bhaskar, V. H. (2014). Trapa bispinosa Roxb.: A Review on Nutritional and pharmacological aspects. Retrieved November 17, 2017, from https://www.hindawi.com/ journals/aps/2014/959830/ 2014

2. Akao, S. Hosoi, Y. and Fujiwara, T. (2011). Utilization of water chestnut for reclamation of water environment and control of cyano-bacterial blooms. Environ Sci Pollut Res Int. 21(3):2249-2255, 2014. doi: 10.1007/s11356-013-2102-2. Epub 2013 Sep 8.

3. Alfasane, Md., Almujaddade, M., Khonder, M., Rahman, M. (2017). Biochemical Composition of the Fruits of Water Chestnut (Trapa bispinosa Roxb.). Dhaka Univ. J. Biol. Sci. 20(1): 95-98, 2011.

4. Besha J.A. and Countryman, W.D. (1980). Feasibility assessment of anaerobic digestion of European water chestnuts (Trapa natans L.). New York State En- 
ergy Research and Development Authority 80-13, Albany, NY.

5. Choudhury, R.S., Sahoo.N and Verma H.N. (2003). Growth behavior and yield of five water chest nut varieties under waterlogged condition. Indian Journal Plant Physiology, 8(4):369-371

6. Faruk, M.O. , Amin, M.Z., Sana N.K., Saha, R.K. and Biswas, R.K. (2012).Biochemical analysis of two varieties of water chestnuts (Trapa spp). Pakisthan Journal of Biological Sciences, 15(21):1019-1026.

7. Hummel, M. and Findlay, S. (2006). Effects of water chestnut (Trapa natans) beds on water chemistry in the tidal freshwater Hudson River. Hydrobiologia. 2559: 169-181.

8. Hummel, M. and Kiviat, E. (2004). Review of world literature on water chestnut with implications for management in North America. J Aquat Plant Manage. 42: 17-27.

9. Jackson, M.L. (1973). Soil Chemical Analysis. Prentice Hall of India Pvt. Ltd., New Delhi.

10.Jana, H. (2016).Water Caltrop: A potential crop of waterbodies. Rastriya Krishi, 11(2) 7-11

11.Kundu, M. and Joshi, R. (2012). Production Technology of water chestnut ( Trapa natans ) Krisi sewa pp1-2

12.Majumdar, B.C. and Jana, S.(1977). Physicochemical analysis of water-chestnut (Trapa bispinosa) fruits. Sci-and-Culture, 43: 8: 361-362.

13.Mann, S., Gupta, D. Gupta, V. and Gupta, R. ( 2011). Evaluation of nutritional, phytochemical, and antioxidant potential of Trapa bispinosa Roxb. fruit. Retrieved November 17, 2017, from http:// www.ijppsjournal.com/Vol-4lssue-1/3050.pdf

14.Puste, A.M. (2004). Agronomic management of wetland crops". Kalyani Publishers, India.

15.Ranganna, S. (1986). In Handbook of analysis and quality control for fruit and vegetable products. 3rd edn. Tata Mc Graw-Hill Publishing, New Delhi, India.

16.Rhoads, A.F. and Morris, Block, T.A. (2002). Arboretum of the University of Pennsylvania. European water-chestnut Trapa natans L. Water chestnut fami- ly (Trapaceae). April 2002. http://www.paflora.org/pdf/ INV-Fact\%20Sheets/Trapa\%20natans.pdf Updated $5 / 12$

17.Singh, G.D., Bawa, A.S, . Singh, S. and Saxena.D.C. (2009). Physicochemical, pasting, thermal and morphological characteristics of Indian water chestnut (Trapa natans) starch. Starch Stärke. 61: 35 $-42$

18.Singh G.D., Singh S, Jandal, N and Saxena D.C. (2010). Physico-chemical characteristics and sensory quality of Singhara (Trapa natans L.): An Indian water chestnut under commercial and industrial storage conditions. African Journal of Food Science,4(11), pp. $693-702$.

19.Singh. I.S. (2017). Dynamics of nutrient of aquatic crop (Gorgon nutor makhana) under different system of cultivation- A review.International Journal of Agriculture Sciences.7(5) pp 1309-1316.

20.Subhiah B.V. and Asija G.L. (1956). A rapid procedure for the estimation of available $\mathrm{N}_{2}$ in soils. Current Science 25, 259.

21.Takano, A. and Kadono, Y. (2005). Allozyme variations and classification of Trapa (Trapaceae) in Japan. Aqu Bot., 83: 108-118.

22.Tang, X.T., Zheng, F.S., Qin, J., Lu, MX, and Du, Y.Z. (2016). Genetic structure of water chestnut beetle: Providing evidence of origin of water chestnut. PLOS ONE, 11(7): e0159557.

23.Tsuchiya, T. and Iwakuma, T. (1993). Growth and leaf life-span of a floating-leaved plant, Trapa natans L., as influenced by nitrogen flux. Aquatic Botany, 46(3-4):317-324.

24.USEPA(1989). Superfund record of decision" Marathon Battery, NY, third remedial action - final. U.S. Environmental Protection Agency, New York State Department of Environmental Conservation, Albany, NY.

25. Yadav, H.S. and Gargav, V.P. (1988). Chemical Control of Singhara Beetle, Galerucella birmanica Jacoby. Indian Journal of Plant Protection. 16:159162 